DOI: $\underline{10.20472 / B M .2020 .8 .1 .005}$

\title{
AIR-TRANSPORTATION, TOURISM AND ECONOMIC GROWTH INTERACTIONS IN SRI LANKA: COINTEGRATION AND CAUSALITY ANALYSIS
}

\author{
WASANTH MADURAPPERUMA, RUWAN HIGGODA
}

\begin{abstract}
:
Air travel growth is one of the notable responsibilities of a government specifically for an economy which depends heavily on tourism. Air travel strengthens destinations by enhancing connectivity, arrivals and other tourism reactions therefore it is recognized as a medium of revenue generation, work opportunity creation and sustainable business development. The aim of this study is to examine the causal relationship between tourism, air travel and economic growth in Sri Lanka for period of 1983-2019. The study employs the Cointegration and Granger causality approach. The results confirm that there is a stable uni directional relationship running from air transportation to economic growth in the short run bidirectional causality exists between air travel and tourism growth in Sri Lanka. The findings suggested that policymakers do not over-rely on air transportation for economic growth and that they pay more comprehensive attention to integrate the air transportation and tourism growth. It recommends policy makers to develop integrated strategies that connect air travel, tourism and economic growth.
\end{abstract}

\section{Keywords:}

Air travel; Tourism, Tourist arrivals, Economic growth (GDP), Cointegration, Vector Error Correction Model; Causality

JEL Classification: L93, 018, C32

\section{Authors:}

WASANTH MADURAPPERUMA, University of Kelaniya, Colombo, Sri Lanka, Email: wasanthi@kIn.ac.Ik RUWAN HIGGODA, Air Traffic Controller, Bandaranaike International Airport, Sri Lanka, Email: ruwanatc.ans@airport.lk

\section{Citation:}

WASANTH MADURAPPERUMA, RUWAN HIGGODA (2020). AIR-TRANSPORTATION, TOURISM AND ECONOMIC GROWTH INTERACTIONS IN SRI LANKA: COINTEGRATION AND CAUSALITY ANALYSIS. International Journal of Business and Management, Vol. VIII(1), pp. 85-107., 10.20472/BM.2020.8.1.005 


\section{Introduction}

The dynamic connection between tourism and air travel has been comprehensively explored in previous research studies and it is found the relationship is strong and mutually dependent (Duval, 2013). As air travel sector plays a key role in the tourism industry in Sri Lanka, changes of air travel has significantly impacted on the tourism sector development (Bieger and Wittmer, 2006). According to Sri Lanka Tourism Development Authority (SLTDA), the total number of international traveller arrivals to Sri Lanka for the month of January 2020 is decreased by $6.5 \%$ with the traffic of 228,434 compared to the month of January 2019 which recorded a traffic of 244,239 which ultimately influenced the demand of air travel (SLTDA, 2020). In 2019, the Easter attack situation impacted on the tourism sector heavily and also declined the air travel demand.

According to SLTDA predictions, tourism contribution towards GDP is expected to grow to $12.5 \%$ in Sri Lanka with the gained credibility and attraction as a destination to travel safe and create lifetime memories (SLTDA, 2019). Also the local currency depreciation could support the sector growth unlike most of the other sectors in the economy. Hotels and resorts generate a higher amount of revenue in dollars from the tourist accommodation and the pricing structure in the country is recognised as competitive and differentiated based on their offerings (SLIDA, 2018). Air travel is an essential factor for a destination in tourism specifically for an Island like Sri Lanka, the air travel sector plays a key role in connecting the country with other regions (Currie and Falconer, 2014). The air travel sector also supports the economic growth, accessibility to product and services, capital management and connecting people with other segments. Economic progression of a country promotes the development of tourism by strengthening the infrastructure, aviation connectivity and standards of living. It is mentioned by many scholars, that the air travel contributed towards the economy in three main ways, direct, indirect and catalytic, therefore the growth of air travel can support the growth of tourism and then the economy (PWC 2015). This impact cycle continues by improving segments and supporting other segments to grow as shown in Figure 1.

Figure 1: Air travel, Tourism and Economic growth cycle

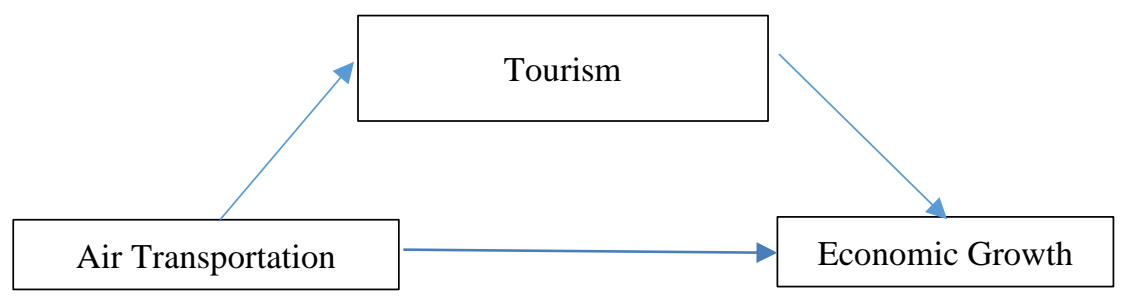

Source: Computed by Author 
Air travel demand heavily correlated with the tourism sector, over the recent years the air travel has increased as a result of the substantial emergence of tourism sector in another aspect, the development of air travel and connectivity supports the development of tourism (Tang C., Weaver D., Lawton L., (2017). Tourism growth boosts accommodation availability, airline connectivity and airport facilities to support travellers, travel agents and destination management companies. Strengthening the air network supports the growth of international tourist arrivals and supports the related areas of travel specifically for an island it is necessary to have well-connected air travel network to succeed in travel. This article focuses on the dynamic and advanced relationship between air travel, tourism development and economic growth and the main objective of the research paper is to determine the catalytic impact of air travel on the economic growth.

The impact of travel improvements and infrastructure progression can impact on travellers differently depending on their connection to the destination and their desires to travel to a certain destination (Olipra L., (2012), Introducing inter-regional high speed railway system can strengthen the travel demand within regions for instance introducing the Singapore-Malaysia high speed railway is expected to generate more travel traffics to the region. In tourism, the time spent on travelling is also recognised as a cost to the traveller, therefore in many scenarios travellers prefer to utilise domestic flights to travel within locations quickly as possible to save time although it is expensive compared to land transportation for instance many travellers use domestic flights in countries such as Australia, India, Thailand and China to save time from land transport (Pagliara et al. 2015).

A destination to be successful in travel, it certainly needs to have a strong air travel connectivity, even though a destination is stronger with communication, prior booking procedures, accommodation, restaurants and related activities it is challenging to grow in tourism with limited accessibility. Countries including Mauritius, Madagascar and Seychelles face the issue of limited air connectivity in growing as a travel destination (Lonely Planet, 2018). It is mentioned by many researchers, accessibility strongly influence the customer preference in selecting a travel destination (Tang C., Weaver D., Lawton L., (2017). Having insufficient or unfitting accommodation can impact certain travel groups for instance having lack of luxury hotels can negatively impact on business travel and honeymoons but it is not a strong factor as accessibility (Currie, et al 2011; Costa, et al, 2017). However, researchers suggest having a limited and insufficient accommodation and food and beverage services can be challenging a destination to grow as a travel destination and to attract travel segments. Regardless the growth of air connectivity and travel infrastructure, impact of inbound services 
and facilities can also be significant towards the development of tourism sector. Despite the availability of research studies (Dobruszkes F., Mondou V., Ghedira A., (2016) on the relationship between air transportation and tourism, quantitative studies on the dynamic relationship are scarce.

The main objective of this research paper is to explore and examine the demand side catalytic impacts of air travel and provide recommendations to further studies. The paper contains four sections, namely introduction including brief literature review, methodology, data analysis and discussion and conclusion.

\section{Method and Methodology}

The dataset used in the empirical analysis combined different sources such as Central Bank of Sri Lanka and, Ministry of Tourism Statistics. Note that this study employs total passenger movement to measure the air transportation. In the analysis all data were expressed logarithmically in order to include the proliferative effect of time series. Annual data from 1983 to 2019 are used for our empirical investigation.

\subsection{Empirical model}

The aim of this study is to determine whether there is a causal relationship between air transportation, tourism and economic growth. Thus, following empirical model as shown in equation (1) was identified in order to examine this causal relationship.

$$
\begin{aligned}
\Delta G D P_{i t} & =\beta 11 p \Delta G D P_{i t-p}+\beta 12 p \Delta T P M_{i t-p}+\beta 13 p \Delta T G_{i t-p}+\gamma_{l i} E C T_{i t-1}+\Delta \varepsilon 1_{i t} \\
\Delta T P M_{i t} & =\beta 21 p \Delta G D P_{i t-p}+\beta 22 p \Delta T P M_{i t-p} \beta 23 p \Delta T G_{i t-p}+\gamma_{2 i} E C T_{i t-1}+\Delta \varepsilon 2_{i t} \ldots \\
\Delta T G_{i t} & =\beta 31 p \Delta G D P_{t-p}+\beta 32 p \Delta T P M_{t-p}+\beta 33 p \Delta T G_{t-p}+\gamma_{3 i} E C T_{t-1}+\Delta \varepsilon 3_{t} \ldots
\end{aligned}
$$

where $\Delta$ is the first difference operator; $\mathrm{GDP}_{\mathrm{t}}$ is the natural logarithm of $\mathrm{GDP}_{\mathrm{t}}$; TPMt is the natural logarithm of total passenger movements, $T_{G_{t}}$ is the natural logarithm of tourist arrivals; $E C T_{t-1}$ is the error correction term lagged by one period coming from the lagged residuals derived from the long-run cointegrated relationship; $\beta_{i}$ are the short-run adjustment coefficients; and $\varepsilon_{\mathrm{t}}$ are error terms.

In this study, the tests for the transportation led growth hypothesis following two steps: Step 1 involved tests for cointegration, and Step 2 involved tests for Granger causality. The vector error-correction modelling (VECM) were employed for testing these the hypotheses that there 
is a causal relationship between air transportation, tourism and economic growth. The study develop following sub hypotheses as follows.

$H(a)$ : Air Transportation (TPM) Granger-causes economic growth (GDP). This is termed the aviation-led growth hypothesis;

$H(b)$ : Tourism development (TG) Granger-causes economic growth (GDP). This is termed the Tourism-led growth hypothesis; and

H(c): Air Transportation Granger-causes Tourism development (TG). This is termed the aviation-led tourism growth hypothesis.

\subsection{Stationarity test}

To investigate the dynamic causal connection between variables, the experimental analysis will first test the integration order of each variable. Stationary tests are first performed for recognising the order of integration of each of the projected variables. In this study, Augmented Dicky Fuller (ADF) test and Philip Peron (pp) tests are employed to validate the variables' order of integration.

\subsection{Johansen cointegration test}

In order to examine the long-run equilibrium connection between air transportation, tourism development and economic growth, the maximum likelihood approach formed by Johansen and Juselius (1990) has been performed. The null hypothesis is that there is no cointegration, while the alternative hypothesis is that there is cointegration between variables. Variations from the long-run equilibrium relationship are represented by the estimated residuals $\varepsilon_{\text {t. }}$ The null hypothesis of no cointegration $\left(\rho_{\mathrm{i}}=1\right)$ is tested via the following unit root test on the residuals:

$\varepsilon_{t}=\rho_{i} \varepsilon_{t-1}+\omega_{t}$

\section{Causality analysis framework}

This study implements dynamic causality tests based on the vector error correction model (VECM) to estimate the short-term and long-term directions of connection between the studied variables. The Granger causality model used in this study is developed on the VECM as shown in question 1, 2 and 3. 


\subsection{Impulse response function and variance decomposition}

The VECM tests can specify only the Granger causality of the dependent variable within the sample period and offer diminutive evidence on the dynamic properties of the system. The Variance Decomposition by segregating the variance of the forecast error of a certain variable into the proportions attributable to innovations (or shocks) in each variable in the system containing its own, can deliver an indication of these dependences and may be characterised as out-of-sample causality tests (Kling \& Bessler, 1985). The variable that is optimally forecast from its own lagged values will have all its forecast error variance explained by its own disturbances (Sims, 1982). Furthermore, Impulse Response Functions (IRFs) display the impacts of innovations on the adjustment path of the variables.

\section{Stability tests}

After modelling the VECM, we performed the diagnostic and stability test for the goodness of fit of the VECM equations. The structural stability was studied by means of the accumulative sum (CUSUM) and CUSUMQ. The CUSUMQ statistics are restructured recursively and planned against the break points. If the plots of the CUSUMQ stat stay within the $5 \%$ critical bound, the null hypothesis for all coefficient in the given regression is said to be stable.

\section{Empirical results}

\subsection{Preview of data}

The historical tendencies of economic growth, air travel and tourism development for Sri Lanka are demonstrated in figure 2 and exhibited that there is a strong correlation between these three series implying that air transportation have experienced the strongest impact for tourism development and economic growth.

Figure 2: correlation of variables, tourism growth, total passenger movement and economic growth

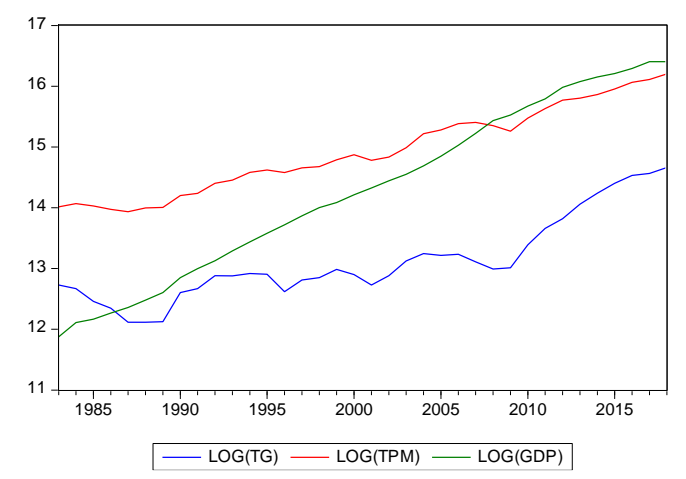

Source: authors' calculations applying Eviews v. 8.0 


\subsection{Descriptive analysis}

Table 1 shown below analyses the descriptive statistics of the data used in this study. When observing the standard deviations, the data calculated for the standard deviation of 1.4, 0.706 and 1.435 which are relatively small, this provides an indication that mean value of Log(GDP), $\log (T P M)$ and $\log (T G)$ is relatively close to the true mean of the overall population. Distributions of all of the variables except log(GDP) are positively skewed. There is no outliers or data entry errors in the sample. The Jarque-Bera normality test rejects the assumption of not normality for all of the variables.

Table 1: Descriptive statistics of the analysis variables

\begin{tabular}{llll}
\hline \hline & Log(GDP) & Log(TPM) & Log(TG) \\
\hline \hline Mean & 14.28041 & 14.92984 & 13.12410 \\
Median & 14.26959 & 14.81129 & 12.91238 \\
Maximum & 16.40457 & 16.20253 & 14.66301 \\
Minimum & 11.87709 & 13.93361 & 12.11516 \\
Std. Dev. & 1.435617 & 0.706627 & 0.695521 \\
Skewness & -0.050456 & 0.202572 & 0.837134 \\
Kurtosis & 1.736256 & 1.833281 & 2.900899 \\
Jarque-Bera & 2.410846 & 2.288062 & 4.219487 \\
Probability & 0.299565 & 0.318532 & 0.121269 \\
Sum & 514.0948 & 537.4743 & 472.4676 \\
Sum Sq. Dev. 72.13484 & 17.47626 & 16.93123 \\
Observations & 37 & 37 & 37 \\
\hline \hline
\end{tabular}

Source: authors' calculations applying Eviews v. 8.0

\subsection{Correlation analysis}

As shown in Table 2, there are evidences for positive $(\rho+)$ correlations opposing to the anticipation, around $98 \%$ of correlations were positive for air travel and economic growth and $88 \%$ between growth rate between tourism development and economic growth. This indicates the lack of explicit relationship between these variables, air transportation, tourism development and economic growth, but correlations do not indicate any causality. 
Table 2: Correlation analysis

\begin{tabular}{llll}
\hline \hline & Log(GDP) & Log(TPM) & Log(TG) \\
\hline \hline Log(GDP) & 1.000000 & 0.985901 & 0.876415 \\
$\log ($ TPM $)$ & 0.985901 & 1.000000 & 0.932210 \\
Log(TG) & 0.876415 & 0.932210 & 1.000000 \\
\hline \hline
\end{tabular}

Source: authors' calculations applying Eviews v. 8.0

\subsection{Stationary properties of the Variables}

Unit root test statistics

Table 3: ADF and PP Tests

\begin{tabular}{|c|c|c|c|c|}
\hline $\begin{array}{l}\text { Using constant } \\
\text { and trend }\end{array}$ & Stationarity & Variables & t-Statistic & $\begin{array}{l}\text { Prob. } \\
\text { value }\end{array}$ \\
\hline I & II & IIII & IV & $\mathrm{V}$ \\
\hline \multirow{6}{*}{$\begin{array}{l}\text { Augmented } \\
\text { Dickey Fuller } \\
\text { (ADF) }\end{array}$} & \multirow{3}{*}{ At level } & LOGGDP & -0.15539 & 0.9916 \\
\hline & & LOGTPM & -2.82665 & 0.1978 \\
\hline & & LOGTG & -1.7505 & 0.7068 \\
\hline & \multirow{3}{*}{ At first difference } & $\triangle \mathrm{LOGTG}$ & -4.9172 & $0.0020^{*}$ \\
\hline & & $\triangle \mathrm{LOGTPM}$ & -4.9505 & $0.0017^{*}$ \\
\hline & & $\Delta$ LOGTG & -4.416966 & $0.0067 /$ \\
\hline \multirow{6}{*}{$\begin{array}{l}\text { Phillips \& } \\
\text { Perron (PP) }\end{array}$} & \multirow{3}{*}{ At level } & LOGGDP & -1.5614 & 0.7872 \\
\hline & & LOGTPM & -2.826 & 0.1978 \\
\hline & & LOGTG & -1.892 & 0.637 \\
\hline & \multirow{3}{*}{ At first difference } & $\Delta$ LOGGDP & -4.9531 & $0.0018^{*}$ \\
\hline & & $\triangle \mathrm{LOGTPM}$ & -4.6789 & $0.0007^{*}$ \\
\hline & & $\Delta$ LOGTG & -4.2297 & $0.0106^{*}$ \\
\hline
\end{tabular}

Note: $\overline{1)^{*},{ }^{* \star} \text { and }{ }^{* \star *} \text { denotes the rejection of the null hypothesis of unit root at } 1 \%, 5 \%}$ and $10 \%$ significance levels. 2) The optimal lag lengths for ADF test are selected by SIC criteria.

\section{Source: authors' calculations applying Eviews v. 8.0}

The first step in this study is to examine the time series properties of the data by using Augmented Dickey Fuller (ADF) test. Table 3 displays the results of Augmented Dicky Fuller test (ADF). Comparing the ADF test statistics with their corresponding critical values, author determine that all the level series of the data have unit roots, however the first difference of all 
series are stationary at $5 \%$ significant level. Therefore, it can be concluded that all series under consideration appear to be integrated to order one i.e. I (1). To confirm the ADF test, the Phillip Perron test (PP) stationary test is also employed. PP test shows that all the level series of the data have unit roots, however the first difference of all series namely, air transportation, tourism development and economic growth are stationary at least at $1 \%$ significant level.

\section{Lag Order Selection}

After determining the integration of the series, that is, all variables are I (1), it is vital to determine the appropriate lag length. If the lag length is not optimum, the error term may not be Gaussian and the inference of the estimation may be invalid. Because the data sample is small, the author only estimates the unrestricted VAR model with all variables from the lag 0 to lag 4. To demine the optimum lag length, the Akaike information criterion (AIC) and Schwarz criterion (SC) are recorded and compared. Table 6.4 shows that the optimal lag length for unrestricted VAR model is one recommended by both AIC and SC. Based on AIC (Akaike Information Criterion) and SIC (Schwartz Information Criterion) the number of lag is chosen as one as shown in table 4 . There is intense interest in the causal relation between air transportation, tourism development and economic growth.

Table 4: VAR Lag model

\begin{tabular}{ccccccc}
\hline \hline Lag & LogL & LR & FPE & AIC & SC & HQ \\
\hline \hline 0 & -16.13532 & NA & 0.000664 & 1.195958 & 1.333370 & 1.241506 \\
1 & $\mathbf{1 3 9 . 8 8 3 6}$ & $\mathbf{2 7 3 . 0 3 3 2 ^ { * }}$ & $\mathbf{6 . 8 1 e - 0 8 ^ { * }}$ & $\mathbf{- 7 . 9 9 2 7 2 7 ^ { \star }}$ & $\mathbf{- 7 . 4 4 3 0 7 6 ^ { \star }}$ & $\mathbf{- 7 . 8 1 0 5 3 3 ^ { \star }}$ \\
2 & 147.1067 & 11.28604 & $\mathbf{7 . 7 4 e - 0 8}$ & -7.881668 & -6.919779 & -7.562829 \\
3 & 153.8866 & 9.322354 & $9.29 \mathrm{e}-08$ & -7.742912 & -6.368784 & -7.287427 \\
4 & 162.1434 & 9.804950 & $1.06 \mathrm{e}-07$ & -7.696462 & -5.910096 & -7.104332 \\
\hline \hline
\end{tabular}

Source: authors' calculations applying Eviews v. 8.0

\section{Cointegration test}

Having verified that all variables are integrated to order one I (1) cannot be rejected, cointegtration test were employed. As this study employ multivariate time series, the multivariate cointegration technique proposed by Johansen (1988) and Johansen and Juselius (1990) is utilised in order to check whether there are stable long-run relations between air 
transportation, tourism economic development and economic growth. The cointegration vectors will be utilized for vector error correction model (VECM).

\section{Table 5: Cointegration test results}

Trend assumption: Linear deterministic trend

Series: LOG(GDP) LOG(TPM) LOG(TG)

Unrestricted Cointegration Rank Test (Trace)

\begin{tabular}{|c|c|c|c|c|}
\hline Hypothesized & & Trace & 0.05 & \\
\hline No. of CE(s) & Eigenvalue & Statistic & Critical Value & Prob. ${ }^{* *}$ \\
\hline None * & 0.487976 & 38.69563 & 29.79707 & $0.0037^{*}$ \\
\hline At most $1^{*}$ & 0.331222 & 15.93657 & 15.49471 & $0.0429^{*}$ \\
\hline At most 2 & 0.064262 & 2.258276 & 3.841466 & 0.1329 \\
\hline \multicolumn{5}{|c|}{ Unrestricted Cointegration Rank Test (Maximum Eigenvalue) } \\
\hline Hypothesized & & Max-Eigen & 0.05 & \\
\hline No. of $\mathrm{CE}(\mathrm{s})$ & Eigenvalue & Statistic & Critical Value & Prob. ${ }^{* *}$ \\
\hline None * & 0.487976 & 22.75906 & 21.13162 & $0.0293^{*}$ \\
\hline At most 1 & 0.331222 & 13.67830 & 14.26460 & 0.0617 \\
\hline At most 2 & 0.064262 & 2.258276 & 3.841466 & 0.1329 \\
\hline
\end{tabular}

${ }^{*}$ denotes rejection of the hypothesis at the 0.05 level

Source: authors' calculations applying Eviews v. 8.0

Trace test and Max-Eigen statistic test are using to determine the cointegration of the variables. As shown in table 5, test statistics 38.69 is greater than 29.79, the 95 percent critical value of the (0) $\lambda$-trace statistic. Therefore, we reject the null hypothesis of no cointegrating vector, and instead we accept that the alternative hypothesis that one or more cointegrating vectors have founded. Next, the $\lambda$-trace statistic is performed to test the null hypothesis of $r$ $\leq 1$ against that the alternative hypothesis of two or three cointegrating vectors $(r>1)$. The (1) $\lambda$ trace statistic is 15.33 , which is less than 95 percent critical value of 58.77 . Hence, there is one cointegrating relation in model. 
Since we have identified the existence of one cointegrating equation, we can say that a stable equilibrium relationship is present. The results are normalized on the GDP as following

Normalized cointegrating coefficients (standard error in parentheses)

$\begin{array}{ccc}\text { LOG(GDP) } & \text { LOG(TPM) } & \text { LOG(TG) } \\ 1.000000 & -2.810931 & 1.054896 \\ & (0.11126) & (0.12109)\end{array}$

In the normalization process, the signs are reversed to enable proper interpretation. The air transport has the expected signs and are statistically significant according to the t values. Firstly, Results shows that a one increase in the level of passenger traffic increase the growth rate of about 2.8 per cent in the long run. A study by ICAO report mentioned that there is a positive relationship between GDP and air transport activity as measured by Revenue Passenger Kilometers over the 20-year period from 1975 to 1995. Such correlation concluded that the air transportation is a useful indicator for economic growth which promotes tourist arrivals. Tourists spend dollars it is boosting the country's foreign exchange reserves. Also, they demand for accommodation, transportation, shopping, sight-seeing and a host of travel related services. This improves air travel infrastructure and pushes up economic activity in all related areas, the spill over impact of air transport on tourism is unquestioned.

Secondly, as per the results, a $1 \%$ increase in the tourism growth leads to a $1.89 \%$ decrease in the economic growth in the long run. It is said that greater numbers of international tourists will lead to more international tourism receipts that will lead to higher GDP. However, in reality, this relationship is not so robust. If the country may attract more tourists with decreasing the prices that might offset the positive additions in visitor numbers. This is because, tourist expenditures during the holiday are not accounted for in the measurement of International tourist arrivals. Also, it reflects only the international component of country's tourism development and it ignores domestic arrivals.

\subsection{Vector Error Correction Models for Dynamic Adjustments}

The error correction terms, ECTt, shown in the table 6 are negative and significant only in equation 1. The $E C T_{t}$, is anticipated to be statistically significant with a negative indication and the negative indication reflects that any shock that happens in the short-run will be modified in the long-term. 
Table 6: Vector Error Correction Models estimates

Standard errors in ( ) \& t-statistics in [ ]

\begin{tabular}{|c|c|c|c|}
\hline Cointegrating Eq: & CointEq1 & & \\
\hline $\operatorname{LOG}(G D P(-1))$ & 1.000000 & & \\
\hline LOG(TPM(-1)) & $\begin{array}{c}-2.810931 \\
(0.11126) \\
{[-25.2636]}\end{array}$ & & \\
\hline $\operatorname{LOG}(\mathrm{TG}(-1))$ & $\begin{array}{c}1.054896 \\
(0.12109) \\
{[8.71167]}\end{array}$ & & \\
\hline C & 13.83946 & & \\
\hline Error Correction: & $\begin{array}{l}\mathrm{D}(\mathrm{LOG}(\mathrm{GDP})) \\
\mathrm{Eq} 1\end{array}$ & $\begin{array}{l}\mathrm{D}(\mathrm{LOG}(\mathrm{TPM})) \\
\mathrm{Eq} 2\end{array}$ & $\begin{array}{l}\mathrm{D}(\mathrm{LOG}(\mathrm{TG})) \\
\mathrm{Eq} 3\end{array}$ \\
\hline CointEq1 & $\begin{array}{r}-0.187143 \\
(0.05153) \\
{[-3.63139]}\end{array}$ & $\begin{array}{c}0.078492 \\
(0.09404) \\
{[0.83469]}\end{array}$ & $\begin{array}{r}0.228798 \\
(0.19146) \\
{[1.19499]}\end{array}$ \\
\hline $\mathrm{D}(\operatorname{LOG}(\mathrm{GDP}(-1)))$ & $\begin{array}{r}-0.176909 \\
(0.18567) \\
{[-0.95279]}\end{array}$ & $\begin{array}{c}-0.402215 \\
(0.33881) \\
{[-1.18715]}\end{array}$ & $\begin{array}{c}0.034663 \\
(0.68982) \\
{[0.05025]}\end{array}$ \\
\hline $\mathrm{D}(\operatorname{LOG}(\operatorname{TPM}(-1)))$ & $\begin{array}{c}-0.111671 \\
(0.15729) \\
{[-0.70996]}\end{array}$ & $\begin{array}{c}-0.129812 \\
(0.28701) \\
{[-0.45229]}\end{array}$ & $\begin{array}{r}-0.923221 \\
(0.58437) \\
{[-1.57986]}\end{array}$ \\
\hline $\mathrm{D}(\operatorname{LOG}(\mathrm{TG}(-1)))$ & $\begin{array}{c}0.180000 \\
(0.09433) \\
{[1.90829]}\end{array}$ & $\begin{array}{c}0.198463 \\
(0.17212) \\
{[1.15306]}\end{array}$ & $\begin{array}{c}0.492591 \\
(0.35044) \\
{[1.40564]}\end{array}$ \\
\hline C & $\begin{array}{c}0.146980 \\
(0.02574) \\
{[5.71011]}\end{array}$ & $\begin{array}{c}0.113657 \\
(0.04697) \\
{[2.41982]}\end{array}$ & $\begin{array}{r}0.084309 \\
(0.09563) \\
{[0.88160]}\end{array}$ \\
\hline R-squared & 0.370551 & 0.320184 & 0.324637 \\
\hline
\end{tabular}

Notes: t-statistics in [ ] and *denotes the rejection of null hypothesis at $5 \%$ level Source: authors' calculations applying Eviews v. 8.0

The adjustment coefficient on GDP is moderately rapid and its speed of convergence to the equilibrium is $18 \%$ in the equation. The coefficients of the error correction term of air transportation and tourism growth are insignificant. Results shows that there is a unidirectional long run causality from both air transportation and tourism development to 
economic growth. It indicates that if there is a disturbance occurred in the whole system, the change of air travel and tourism development will have significant force tending to bring the model back into equilibrium whenever it moves too far as shown in the following figure 3.

\section{Figure 3: Cointegration Graph}

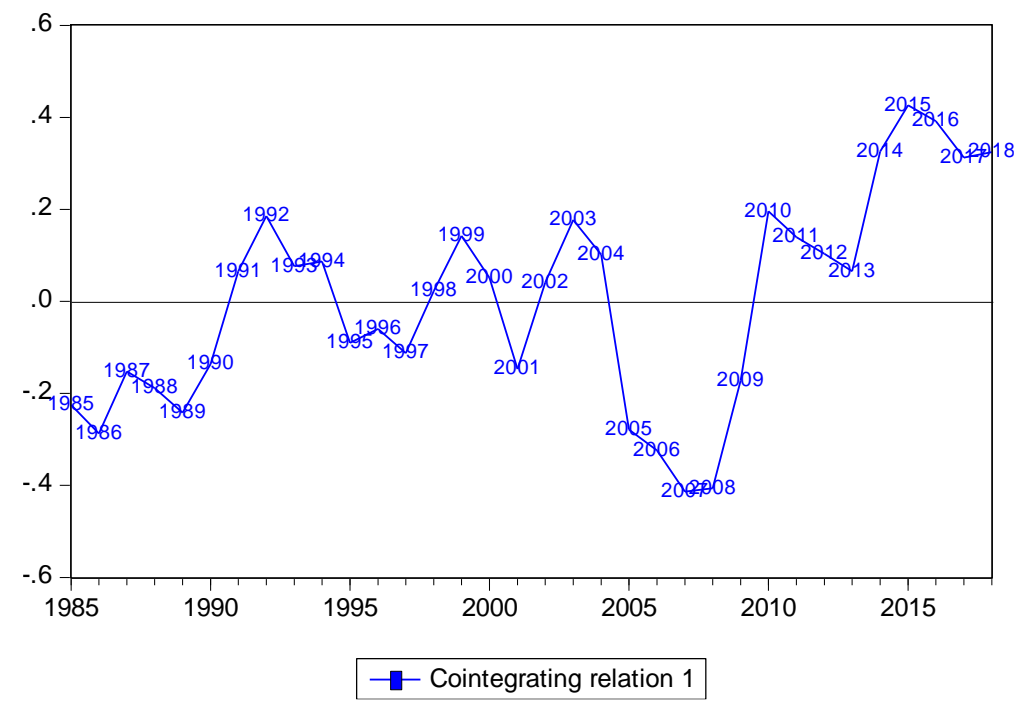

Source: authors' calculations applying Eviews v. 8.0

The short-run dynamics are apprehended through the individual coefficients of the difference terms. According to the equation (1), only $\mathrm{TG}_{\mathrm{t}}$ has positive and significant short-term influences on economic grwoth, implying that $T G_{t}$ could play an important adjustment factor as the system departs from the long-term equilibrium. It can be said that the policies may stabilize tourism growth when endeavoring to promote economic development in Sri Lanka. The table 6.8 further reports that $R^{2}$ values are $37 \%, 32 \%$ and $32 \%$ for equations (1), (2) and (3) respectively.

\subsection{Model Efficiency}

Table 7 displays that diagnostic test such as serial correlation, heteroscedasticity, and normality test were carried out. Firstly, the AR (LM) test was performed to test for serial correlation. The result indicated that the probability of 0.6523 is greater than the significance level of 0.05 . Therefore, we cannot reject the null hypotheses of no serial correlation, secondly, the Breausch-pagan-Gaodfrey test was utilised to test of heteroscedasticity. The results display that the probability of 0.8113 is greater than the significant level of 0.05 hence we fail to reject the null hypotheses of no heteroscedasticity. Thirdly, the normality test was utilised to analyse the normal distribution of the residuals, the test results indicated that the probability value of 0.4351 is greater than the significance level 0.05 which means that we cannot reject 
the null hypothesis as there is a normal distribution of residuals as shown in Figure 4. Fourthly, the chow break point test for structural change highlighted that there is no structural break in the model therefore, we fail to reject the null hypothesis of no structure change before and after war. All the diagnostic tests reveal that the model is appropriately quantified, therefore, these tests support the statistical fitness of the equation.

Table 7: Diagnostic tests

\begin{tabular}{llll}
\hline \hline Test & Null hypothesis & $\begin{array}{l}\text { t- } \\
\text { statistics }\end{array}$ & Probability \\
\hline \hline $\begin{array}{l}\text { AR(LM) test } \\
\begin{array}{l}\text { Breausch-pagan-Gaodfrey } \\
\text { test }\end{array}\end{array}$ & No serial correlation & 0.8543 & 0.6523 \\
Normality test & No heteroscedasticity & 5.2574 & 0.8113 \\
Chow break point test & $\begin{array}{l}\text { There is normal distribution } \\
\text { No structure change before and } \\
\text { after war } \\
\text { (before 2009) }\end{array}$ & 1.6641 & 0.4351 \\
\hline \hline
\end{tabular}

Notes: t-statistics in [ ] and *denotes the rejection of null hypothesis at $5 \%$ level

Source: authors' calculations applying Eviews v. 8.0

Figure 4 : Residual distribution of economic growth, air transportation and tourism
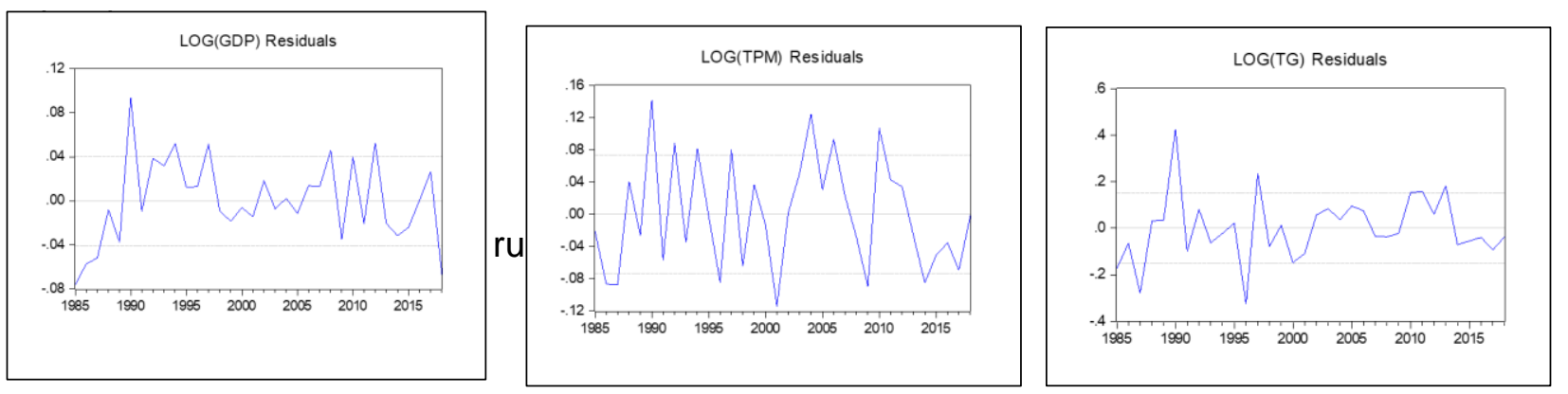

Source: authors' calculations applying Eviews v. 8.0

\subsection{Short run Causality}

Results in table 8 point out that bidirectional causal association is found from tourism to air transport at $5 \%$ significant level. The hypothesis that air travel does not Granger causes economic growth has not been rejected at the level of significance of 0.01 and the reverse hypothesis also accepted at 0.01 . Similarly, results show that there is a short run causality running from economic growth to air transportation. 
Table 8: Pairwise Granger Causality Tests

\begin{tabular}{lccc}
\hline \hline Null Hypothesis: & Decision & F-Statistic & Prob. \\
\hline \hline Log(TPM) does not Granger Cause Log(GDP) & No causality & 1.96935 & 0.1578 \\
Log(GDP) does not Granger Cause Log(TPM) & SR causality & 8.65514 & $0.0011^{*}$ \\
\hline \hline Log(TG) does not Granger Cause Log(GDP) & No causality & 4.74554 & 0.0165 \\
Log(GDP) does not Granger Cause Log(TG) & SR causality & 4.96321 & $0.0140^{*}$ \\
\hline \hline Log(TG) does not Granger Cause Log(TPM) & No causality & 3.49567 & 0.0436 \\
Log(TPM) does not Granger Cause Log(TG) & SR causality & 5.46538 & 0.0097 \\
\hline \hline
\end{tabular}

Notes: t-statistics in [ ] and *denotes the rejection of null hypothesis at 5\% level

Source: authors' calculations applying Eviews v. 8.0

According to the VECM, In the short run, tourism development could play an essential adjustment factor to the economics as the system departs from the long-term equilibrium. The result in cointegration equation show that in the long run, air transportation impact on GDP through tourism growth. Following causal relationship as shown in Figure 5 were identified. It supports the hypothesis of aviation led-growth model

Figure 5: Causal relationship between economic growth, air transportation and tourism

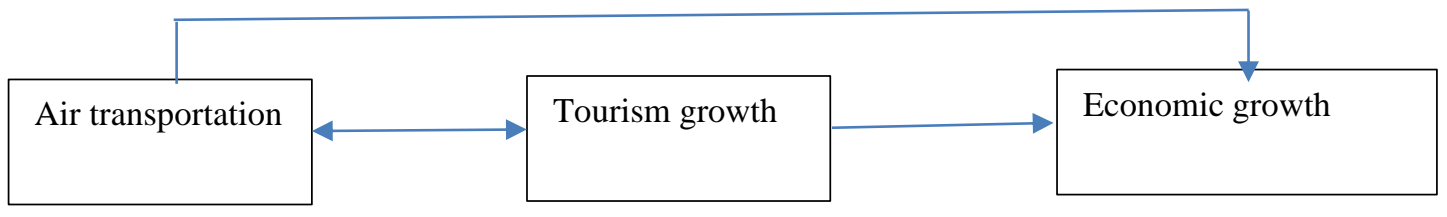

Source: authors' own construction

\subsection{Impulse Response and Variance Decomposition}

To examine the response of the dependent variable in a Vector Autoregressive model to shocks or innovations in the error terms, the Impulse Response Function (IRF) and the Variance Decomposition (VDC) are employed in this study. The two techniques helped to trace the response of GDP growth to shocks in the error terms for several periods in the future.

\section{Variance decomposition}

The variance decomposition specifies the amount of evidence each variable adds to the other variables in the auto-regression. It defines how much of the forecast error variance of each of the variables can be described by exogenous shocks to the other variable. 
Table 9: Variance Decomposition

\begin{tabular}{|c|c|c|c|c|}
\hline \multirow[b]{2}{*}{ Period } & \multicolumn{4}{|c|}{ Variance Decomposition of LOG(GDP): } \\
\hline & S.E. & LOG(GDP) & LOG(TPM) & LOG(TG) \\
\hline 1 & 0.040344 & 100.0000 & 0.000000 & 0.000000 \\
\hline 2 & 0.062499 & 85.14366 & 14.77551 & 0.080829 \\
\hline 3 & 0.080562 & 72.78471 & 25.40785 & 1.807443 \\
\hline 4 & 0.098233 & 61.69047 & 33.26051 & 5.049017 \\
\hline 5 & 0.115529 & 52.84895 & 38.90487 & 8.246177 \\
\hline 6 & 0.131714 & 46.51870 & 42.70965 & 10.77165 \\
\hline 7 & 0.146514 & 42.13651 & 45.25376 & 12.60973 \\
\hline 8 & 0.159988 & 39.08494 & 47.00196 & 13.91310 \\
\hline 9 & 0.172330 & 36.90886 & 48.24902 & 14.84212 \\
\hline \multirow[t]{2}{*}{10} & 0.183749 & 35.30588 & 49.17382 & 15.52030 \\
\hline & \multicolumn{4}{|c|}{ Variance Decomposition of LOG(TPM): } \\
\hline Period & S.E. & LOG(GDP) & LOG(TPM) & LOG(TG) \\
\hline 1 & 0.073618 & 30.48033 & 69.51967 & 0.000000 \\
\hline 2 & 0.106480 & 24.87741 & 67.86063 & 7.261955 \\
\hline 3 & 0.128308 & 25.39930 & 55.18061 & 19.42008 \\
\hline 4 & 0.150671 & 26.40743 & 42.37298 & 31.21959 \\
\hline 5 & 0.173422 & 26.99150 & 32.90867 & 40.09983 \\
\hline 6 & 0.195104 & 27.33690 & 26.50429 & 46.15881 \\
\hline 7 & 0.215111 & 27.59316 & 22.17749 & 50.22935 \\
\hline 8 & 0.233422 & 27.80335 & 19.16722 & 53.02943 \\
\hline 9 & 0.250259 & 27.97857 & 16.98924 & 55.03219 \\
\hline \multirow[t]{2}{*}{10} & 0.265891 & 28.12405 & 15.34864 & 56.52731 \\
\hline & \multicolumn{4}{|c|}{ Variance Decomposition of LOG(TG): } \\
\hline Period & S.E. & LOG(GDP) & LOG(TPM) & LOG(TG) \\
\hline 1 & 0.149889 & 24.45082 & 29.22319 & 46.32599 \\
\hline 2 & 0.247838 & 18.21895 & 13.89148 & 67.88957 \\
\hline 3 & 0.337170 & 16.62550 & 7.508579 & 75.86592 \\
\hline 4 & 0.417692 & 16.25635 & 4.967338 & 78.77631 \\
\hline 5 & 0.487969 & 16.17000 & 3.713214 & 80.11679 \\
\hline 6 & 0.549129 & 16.17671 & 2.977765 & 80.84552 \\
\hline 7 & 0.603123 & 16.21594 & 2.491975 & 81.29208 \\
\hline 8 & 0.651751 & 16.25951 & 2.145743 & 81.59474 \\
\hline 9 & 0.696388 & 16.29746 & 1.886013 & 81.81653 \\
\hline 10 & 0.738004 & 16.32792 & 1.683648 & 81.98843 \\
\hline
\end{tabular}

Source: authors' calculations applying Eviews v. $\mathbf{8 . 0}$

The variance decomposition for the VAR model is presented in Table 9. In this analysis, we proceed to decompose the fluctuations of the response variables (air transportation and 
economic growth) that arise from these aforementioned shocks in the VAR system. The results indicate that changes in air transportation and tourism growth account for a substantial share of the fluctuation in GDP. Air transportation accounts for $14 \%, 38 \%$ and $49 \%$ of the total variance of GDP after two, five and 10 years respectively. The corresponding figures for the tourism shocks are $0.08 \%, 8.2 \%$ and $15.5 \%$ respectively. Meanwhile, the fluctuation of Air transportation is mainly explained by air travel shocks. Tourism development accounts for $7.6 \%, 40 \%$ and $56 \%$ of the total variance of air transportation after one, five and 10 years respectively GDP has the second most important influence and accounts for $24.8 \%$ after one year and $28.12 \%$ after three years. Meanwhile, the tourism growth is mainly explained by shock of own variable. air transportation accounts for $18 \%$ in the short run. It contributes $13 \%$ in long run. GDP has the second most important influence and accounts for $16 \%$ after one year and $1.6 \%$ after 10 years. Therefore, the variance decomposition results bolster the Granger causality finding explained above.

\section{Impulse Response Functions}

The empirical results of the application of the IRF to our model are as shown in Table 10(a); 10(b) and 10(c),

\section{Table 10(a) : Impulse Response Function of GDP}

\begin{tabular}{llll}
\multicolumn{4}{l}{ Response of LOG(GDP): } \\
Period LOG(GDP) & LOG(TPM) & LOG(TG) \\
& & & \\
1 & 0.040344 & 0.000000 & 0.000000 \\
2 & 0.041208 & 0.024024 & -0.001777 \\
3 & 0.037392 & 0.032740 & -0.010684 \\
4 & 0.035058 & 0.039503 & -0.019233 \\
5 & 0.033177 & 0.044531 & -0.024767 \\
6 & 0.031885 & 0.047085 & -0.027715 \\
7 & 0.031221 & 0.048008 & -0.028950 \\
8 & 0.030970 & 0.048130 & -0.029230 \\
9 & 0.030931 & 0.047938 & -0.029095 \\
10 & 0.030977 & 0.047688 & -0.028853
\end{tabular}

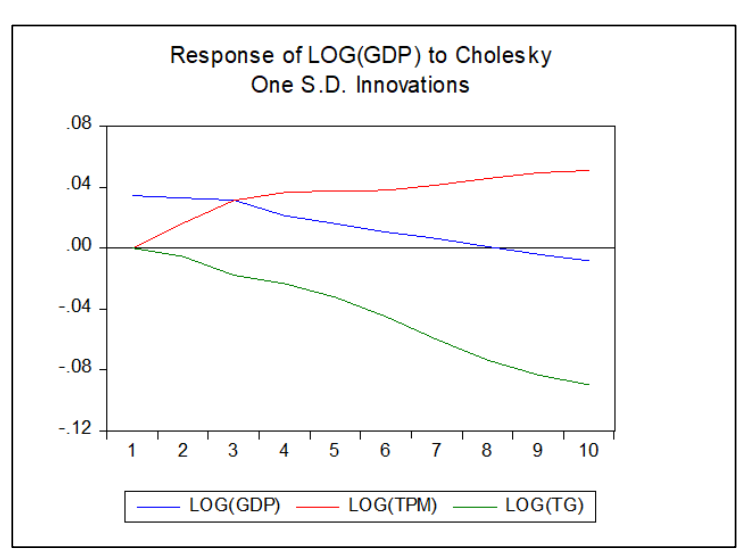

Source: authors' calculations applying Eviews v. 8.0

Economic growth had a positive response to air transportation positively over the period. On the other hand, economic growth responded negatively to tourism growth over the period. It is also observed that the impulse response of GDP to its own shocks was positive over the period. 
Table 10(B) : Impulse Response Function of Air transportation

\begin{tabular}{llll}
\multicolumn{3}{l}{$\begin{array}{l}\text { Response of LOG(TPM): } \\
\text { Period }\end{array}$} \\
& & & \\
1 & 0.040644 & 0.061381 & 0.000000 \\
2 & 0.034186 & 0.062661 & 0.028694 \\
3 & 0.036890 & 0.037286 & 0.048721 \\
4 & 0.042585 & 0.023133 & 0.062372 \\
5 & 0.046074 & 0.016670 & 0.070517 \\
6 & 0.047836 & 0.013846 & 0.074233 \\
7 & 0.048602 & 0.013156 & 0.075311 \\
8 & 0.048794 & 0.013466 & 0.075174 \\
9 & 0.048724 & 0.014031 & 0.074652 \\
10 & 0.048582 & 0.014521 & 0.074143
\end{tabular}

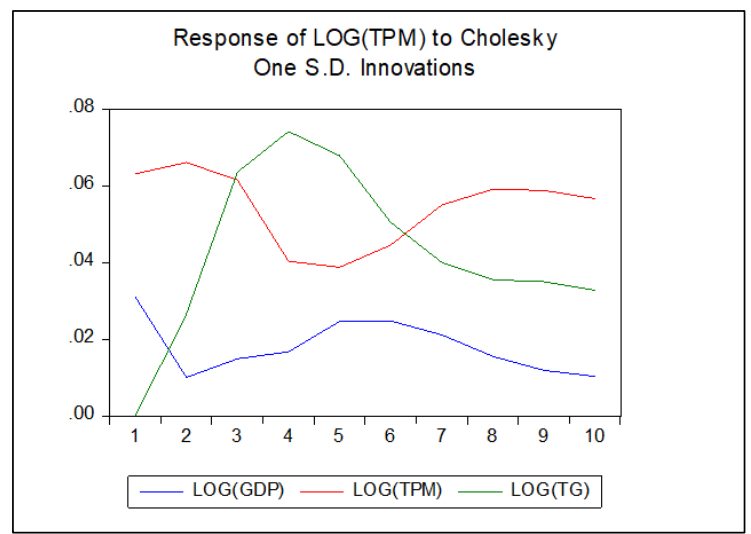

Source: authors' calculations applying Eviews v. 8.0

Air transportation responded positively to tourism growth and the economic growth over the period. impulse response of air transportation to its own shocks was also positive throughout the period.

Table 10(c) : Impulse Response Function of Tourism development

\begin{tabular}{|c|c|c|c|}
\hline \\
\hline \multicolumn{2}{|c|}{ Period LOG(GDP) } & LOG(TPM) & LOG(TG) \\
\hline 1 & 0.074117 & 0.081028 & 0.102019 \\
\hline 2 & 0.075481 & 0.044353 & 0.176896 \\
\hline 3 & 0.087805 & 0.001841 & 0.211061 \\
\hline 4 & 0.097270 & -0.011417 & 0.226255 \\
\hline 5 & 0.100703 & -0.013241 & 0.230935 \\
\hline 6 & 0.101373 & -0.011727 & 0.230248 \\
\hline 7 & 0.101030 & -0.009248 & 0.227865 \\
\hline 8 & 0.100401 & -0.007066 & 0.225592 \\
\hline 9 & 0.099843 & -0.005628 & 0.224003 \\
\hline 10 & 0.099470 & -0.004862 & 0.223103 \\
\hline
\end{tabular}

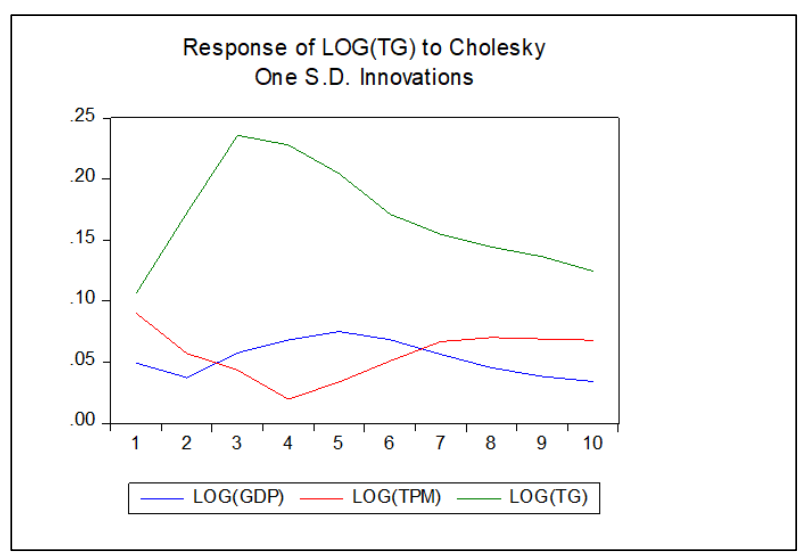

Cholesky Ordering: LOG(GDP) LOG(TPM) LOG(TG)

Source: authors' calculations applying Eviews v. 8.0 


\subsection{Model Stability}

Since the objective of this research focuses on the connection between air transportation, tourism development and economic growth, emphasis is positioned on the stability of the measurements of estimated ECMs. The inverse roots of AR (Auto-Regressive) characteristics polynomial graph shown in figure 6 (a) found that all the lag points are positioned inside of the unit circle, which specifies the satisfaction of VECM stability condition. The constancy of the parameters of the ECMs is measured by applying the CUSUM and CUSUMQ (refer figure 6 (b). As it can be seen from the CUSUM plots, there is no movement outside the $5 \%$ critical lines, suggesting parameter stability. The estimated models for FDI, TPM and GDP are stable.

Figure 6 (a) : Inverse roots of AR

Figure 6 (b): CUSUM and CUSUMQ models

Inverse Roots of AR Characteristic Polynomial

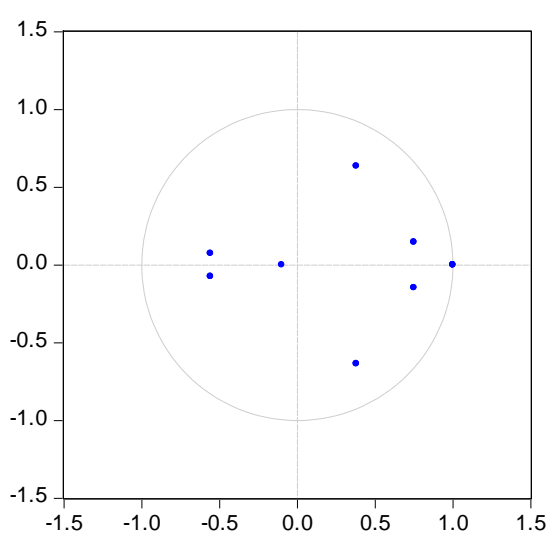

Source: authors' calculations applying Eviews v. 8.0

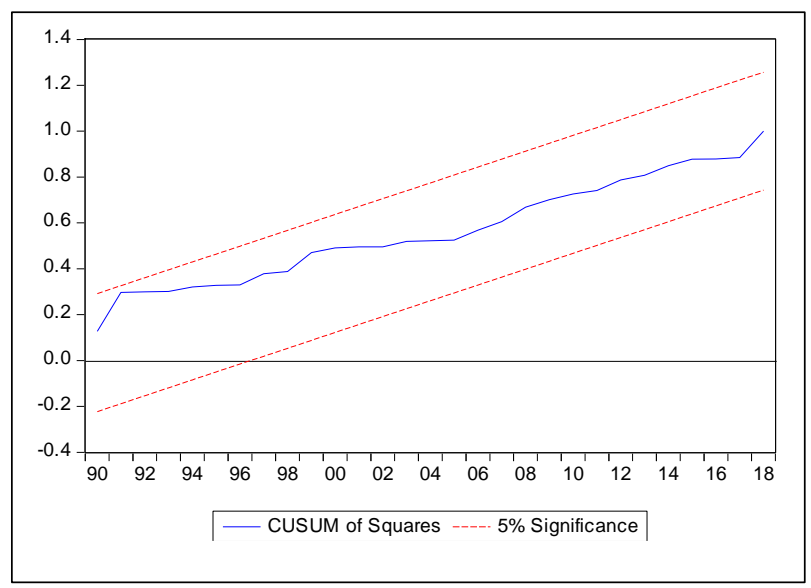

- CUSUM of Squares ----. $5 \%$ Significance

\section{CONCLUSION AND POLICY IMPLICATIONS}

The paper examines the dynamic relationships between air transport, international tourism and economic growth in Sri Lanka for the period from 1983 to 2019. The long-term relationships between these variables are captivating and are of critical interest to policy makers. Using cointegration, suggested by Pesaran et al. (2001), composed with the VECM method, the study develops the following conclusions.

The results display that there is a stable long run uni directional relationship from both air transportation and tourism development to economic growth in sri Lanka. In the short run, international tourism plays a significant and positive role in promoting economic growth. Results further indicates that there exists a bi-directional relationship between air transportation and tourism development. That may have been due to the point that 
international traveller considers transportation performance in the country to take their destination preference related decisions. Growth in the air transport and tourism sectors within Sri Lanka improves regional competitiveness and supports economic, social and intercultural development.

As a result of this study, it is likely to express that any threat on air transportation will effect on tourism and then to economic growth as tourism growth is a major contributing factor for country's economic growth as well as to air transport growth. Furthermore, future growth of air transportation depends on not just economic affluence but also on tourism growth. Therefore, governments should work on boosting economic activity, preventing any obstacles in tourism activities.

Our results further provide the rationale for the Government objective of investing in air transportation as a means of stimulating growth over the long term. As there is an indication that forward and backward linkages are not as fully developed as they could be, and initiatives should also be put in place to foster stronger linkages between the air transportation and other sectors, such as tourism. It is suggested to policymakers do not over-rely on air transportation for economic growth and that they pay more comprehensive attention to tourism growth (example, Mattala).

However, such an analysis might also provide a deceptive causal relationship due to the elimination of other time-varying covariates such as foreign direct investment and trade that may have significant impacts on the model. It is significant to consolidate such variables in the analysis and increase upon the model exhibited here. Moreover, this research produces only quantitative evidence of the catalytic impacts of air transportation, it is beyond the scope of this study to investigate how these quantitative effects are interpreted in a real-world context. This study also employed a different model at the same time to gain more insightful information and fruitful results for future research. 


\section{REFERENCES}

Bieger, T., \& Wittmer, A. (2006). Air transport and tourism-Perspectives and challenges for destinations, airlines and governments. Journal of Air Transport Management, 12(1), 40- 46. https://doi.org/10.1016/j.jairtraman.2005.09.007

Costa, V.; Conceição, O. e Almeida, C.R, (2017), Air transport and tourism destinations: the case of Oporto Airport and Portugal's Northern Region, Tourism Spectrum, Vol.3., No. 1, March 2017, 5th Issue, 41-49

Currie, C., \& Falconer, P. (2013). Maintaining sustainable island destinations in Scotland: The role of the transport- tourism relationship. Journal of Destination Marketing \& Management. https://doi.org/10.1016/j.jdmm.2013.10.005

Dobruszkes F., Mondou V., Ghedira A., (2016), Assessing the impacts of aviation liberalisation on tourism: Some methodological considerations derived from the Moroccan and Tunisian cases, Journal of Transport Geography 50, $115 \quad$ - 127. https://doi.org/10.1016/j.jtrangeo.2015.06.022

DICKEY, D., FULLER, W. Distributions of the Estimators for Autoregressive Time Series with a Unit Root. Journal of the American Statistical Association, 1979, Vol. 74, pp. 427-431. https://doi.org/10.1080/01621459.1979.10482531

DICKEY, D.A. AND FULLER, W.A., Likelihood ratio statistics for autoregressive time series with a unit root. Econometrica, 1981, 49: 1057- 1072. https://doi.org/10.2307/1912517

JOHANSEN, S., JUSELIUS, K. Maximum likelihood Estimation and Inference on Cointegration with Application to the Demand for Money. Oxford Bulletin of Economics and Statistics, 1990, Vol. 52, pp. 162-211.

JOHANSEN, S., Statistical analysis of cointegration vectors". Journal of Economic Dynamics and Control, 1988, 12: 231-254. https://doi.org/10.1016/0165-1889(88)90041-3

JOHANSEN, S., Likelihood-Based Inference in Cointegrated Vector Autoregressive Models, Advanced Texts in Econometrics, 1995, Oxford University Press, Oxford. https://doi.org/10.1093/0198774508.001.0001 
Kling, J. L., \& Bessler, D. A. (1985). A comparison of multivariate forecasting procedures for economic time series. International Journal of Forecasting, 1, 5-24. doi:10.1016/S0169-2070 (85)80067-4.

Pagliara, F., La Pietra, A., Gomez, J., Vassallo, J.M (2015), High speed rail and the tourism Market: evidence from the Madrid Case study, Transport Policy, 37, pp. 187-194. https://doi.org/10.1016/j.tranpol.2014.10.015

Sims, C. A. (1982). Policy analysis with econometric models. Brookings Papers on EconomicActivity, 1982,107-164.

Retrieved from http://www.brookings.edu/ /media/projects/bpea/ 1982\%201/1982a_bpea_sims_goldfeld_sachs.pdf. https://doi.org/10.2307/2534318

Toda, H.Y., Phillips, P.C.B., 1993. Vector autoregressions and causality. Econometrica 61, 1367-1393. https://doi.org/10.2307/2951647

Toda, H.Y., Phillips, P.C.B., 1994. Vector autoregression and causality: a theoretical overview and simulation study. Econometric Reviews

13 , 259-285. https://doi.org/10.1080/07474939408800286

Toda, H.Y., Yamamoto, T., 1995. Statistical inference in vector autoregressions with possibly integrated processes. Journal of Econometrics 66, 225-250. https://doi.org/10.1016/03044076(94)01616-8

PWC 2015, Connectivity and Growth - Issues and challenges for Airport Investment,accessed:https://www.pwc.com/gx/en/capital-projectsinfrastructure/publications/assets/connectivity-growth-airport-investment.pdf

Olipra L., (2012), The impact of low-cost carriers on tourism development in less famous destinations, Referred Electronic Conference Proceeding ISBN 978-88-907394-1-5, CITTASLOW: il valore della lentezza per il turismo del futuro, Perugia/Orvieto, 13-14 giugno 2012

Rodrigue, J., Comtois , C., \& Slack, B. (2006). The Geography of Transport Systems. Routledge 
Tang C., Weaver D., Lawton L., (2017), Can stopovers be induced to revisit transit hubs as stayovers? A new perspective on the relationship between air transportation and tourism, $\begin{array}{llll}\text { Journal of } \quad \text { Air } & \text { Transport }\end{array}$ https://doi.org/10.1016/j.jairtraman.2017.02.008

Tang, C. \& Weaver, D. (2013), The Quasi-destination as an Innovative Component of Tourism System - Evidence from Singapore. Presented at The International Conference on Tourism Transport and Logistic. Paris, France

United Nations Environment Program (2011) Tourism: investing in energy and resource efficiency. http://www.unep.org/resourceefficiency/Portals/24147/scp/business/tourism/green economy_tourism.pdf

WORLD BANK REPORT, 2018, http://documents.worldbank.org/curated/en/716781571813265877/pdf/Air-Transport-AnnualReport-2018.pdf

World Bank (2014) World development indicators;

http://www.worldbank.org/data/onlinedatabases/onlinedatabases.html

World Travel \& Tourism Council (2018) Travel \& tourism: economic impact 2018 Latin America. https://hi-tek.io/assets/tourism-statistics/LatinAmerica2018.pdf http://www.slida.lk/slidatest/index.php?lag=en

https://www.lonelyplanet.com/articles/best-in-travel-2018-top-10-countries 